\title{
Research on Optimal Allocation Model of Water Resources in Urban Area of Tai'an City
}

\author{
Jie Dong, Xiu Cui Tan, Yan Fang Diao and Gang Wang \\ College of Water Conservancy and Civil Engineering, Shandong Agricultural University, Taian, \\ Shandong, China.
}

KEYWORDS: multi-objective optimization; water resource allocation; supply and demand analysis; Abstract. The method of multi-objective optimization is used to research optimal allocation model of water resources in urban area of Tai'an City. The supply and demand situation of water resources is analyzed. The optimal allocation scheme is given, which includes basic and recommended scheme of the planning year. By reasonable allocation, the demand of domestic water, industrial water and ecological water can be guaranteed in wet years and normal years. In dry years, water resource is scarce, so water conservation measures or water diversion still need to be taken for sustainable use of water resources.

\section{INTRODUCTION}

\section{Introduction}

Optimal water resource allocation is the foundation of reasonable development and sustainable utilization of water resource, the importance of which is especially revealed in coordinating society, economy, energy and environment, faced with severe shortage of water resource and the urgent demand for the fast social and economic development[1-3].

Optimal water resource allocation started with Colorado University in the 1960s. It was a research conducted on the prediction of water demand and its related solutions. In the 1980s, it became an academic research interest in China. At present, water resource optimization allocation includes optimization allocation based on systematic theory, sustainable development, ecology, and ET, etc [4-8].

\section{Research area}

Tai'an is a prefecture-level city in central Shandong Province, which is an important opening tourism city of East China. It lies in the south of Mt Tai and has an area of $233.5 \mathrm{~km}^{2}$.Most part of it is on the alluvial fan and the eastern and southern parts are slanting plain with a topography of north being high and south low. The surface elevation is $140 \sim 200 \mathrm{~m}$. Seven rivers belonging to the reaches of the Yellow River flow through the city. The water volume typical of mountain torrent river with seasons.

With the completion of Dawen River impounding projects and Shengli reservoir reinforcement project, a new pattern of water supply will appear in urban area of Tai'an City. This proposes higher requirements for water resources allocation, operation mechanism, management system, and scientific scheduling. The urban water supply system is multi-target, multi-variable, and multi-level. It is particularly important to maximize its benefits due to the limited water resources. Therefore, optimal allocation and unified scheduling of water resources will help optimize the structure of urban water resources and pattern of water supply and improve security capabilities of urban water supply.

\section{Research contents}

The optimal allocation of water resources is the main research content. The research coverage is the main urban area of Tai'an City. By supply and demand analysis of water resources, the optimal allocation program is given.

The research is based on the program of water supply and demand in the current year (2012) and the planning year (2020). The multi-objective optimization methods are used for optimal allocation of water supply, which proposes the basic and recommended schemes of the planning year and the 
main conclusions and recommendations of optimal allocation of water resources in urban area of Tai'an City.

\section{ALLOCATION MODEL OF WATER RESOURCES}

\section{Objective function}

The main purpose of water resources allocation is to study how to use various water sources in urban area of Tai'an City. High quality water is preferentially used as domestic water (such as Huangqian reservoir and groundwater). Water of Dawen River impounding projects and Shengli reservoir is used as industrial water. So the high quality water is replaced, water competition caused by water shortage is alleviated. The main objective function is the comprehensive economic benefit of regional water supply in city. The difference of social efficiency is small in different water resources allocation scheme that water shortage is evaluating indicator. Therefore, the multi-objective problem is changed into single objective problem that the overall economic efficiency is the largest. The objective function expressions as follows:

$$
\max f(x)=\max \left\{\sum_{k=1}^{k} \sum_{j=1}^{J(k)}\left[\sum_{i=1}^{I(k)} b_{i j}^{k} x_{i j}^{k} \alpha_{i}^{k}\right] \lambda_{j}^{k} \beta_{k}\right\}
$$

Where, $x_{i j}^{k}$ represents water supply from water sources $i$ to water user $j$ in the sub-district $k\left(10^{4} \mathrm{~m}^{3}\right)$; $b_{i j}^{k}$ represents water supply efficiency coefficient from water sources $i$ to water user $j$ in the subdistrict $k\left(\right.$ yuan $\left./ \mathrm{m}^{3}\right) ; \alpha_{i}^{k}$ represents water supply order coefficient from water sources $i$ to the subdistrict $k ; \lambda_{j}^{k}$ represents water use fair coefficient of water user $j$ in the sub-district $k ; \beta_{k}$ represents weight coefficient of the sub-district $k$.

Efficiency coefficient is determined by the output value of water consumption per cubic meter in each industry. The order of water supply is that water resources in the region is used firstly, followed by the diverted water, reused waste water, surface water, finally, groundwater. The order of water users is to meet domestic and ecological water firstly, then the secondary and tertiary industries are considered (The primary industry isn't considered in urban area).

\section{Constraint conditions}

The transmission capacity of river channel and pumping station is limited indifferent district. Therefore, during the calculation of water resources allocation, water supply from water sources to water users of the sub-district should not be greater than the maximum water transmission capacity, such as the formula (2).

$$
X_{i j}^{k} \leq Q_{\max , i k}
$$

Where, $Q_{\max , i k}$ represents the transmission capacity from water sources $i$ to the sub-district $k$ in planning year.

$80 \%$ of urban domestic water is from Huangqian Reservoir and $20 \%$ from two underground water sources in Dongwu and Jiuxian. Jueyu Reservoir and Caishang Reservoir are two reserve reservoirs.

The water supply amount of water users from water sources to the sub-district is not lower than water consumption of different industries, such as formula (3)

$$
D_{j \text { min }}^{k} \leq \sum_{j=1}^{J(k)} X_{i j}^{k} \leq D_{j \text { max }}^{k}
$$

Where, the guaranteed rate of water use in secondary industries is an important indicator reflecting the economic stability, which is not less than $90 \%$ for each sub-district.

The water consumption of each water user is not negative in any district. The amount of water supply can meet the needs of each water user, such as formula (4).

$$
X_{i j}^{k} \geq 0
$$


Where, $X_{i j}^{k}$ represents water supply from water sources $\mathrm{i}$ to water user $\mathrm{j}$ in the sub-district k.

\section{MODEL APPLICATION}

\section{Water supply and demand scheme settings}

The optimal allocation of water resource is focused on the urban area of Tai'an city. The supply and demand balance analysis is based on the current year and the planning year. We can generally grasp the water shortage situation of urban area from balance analysis results.

In the current year (2012), the supply and demand schemes include basic scheme (without water saving) and recommended scheme (strengthening water saving, reducing the use of groundwater). In basic scheme, the water supply includes surface water, groundwater, guest water and unconventional water. There is larger water saving potential for the second and tertiary industries. By improving water-saving technologies, water requirement quota of the second and tertiary industries can be reduced. The new water diversion project is constructed to meet the needs of urban development on water resources.

In the planning year (2020), the supply and demand schemes include basic scheme (without water saving) and recommended scheme (strengthening water saving, reducing the use of groundwater). In basic scheme, the water supply includes surface water, groundwater, guest water (three water source projects outside the area and the reserve water source projects) and unconventional water. There is larger water saving potential for the second and tertiary industries. By improving watersaving technologies, water requirement quota of the second and tertiary industries can be reduced.

The water supply and demand balance analysis are shown in Table 1- Table 4.

Table 1.The supply and demand balance analysis of water resources in urban area Unit: $10^{4} \mathrm{~m}^{3}$

(Basic planning year 2012)

\begin{tabular}{llll}
\hline Scheme & $\mathrm{P}=50 \%$ & $\mathrm{P}=75 \%$ & $\mathrm{P}=95 \%$ \\
\hline $\begin{array}{l}\text { Water } \\
\text { Supply }\end{array}$ & 12035.14 & 10378.515 & 8334.543 \\
Water & 9088.59 & 9088.59 & 9088.59 \\
$\begin{array}{l}\text { Demand } \\
\text { Water }\end{array}$ & 2946.56 & 1289.93 & -754.04 \\
$\begin{array}{l}\text { Shortage } \\
\begin{array}{l}\text { Water Short- } \\
\text { ageRate }\end{array}\end{array}$ & $32.42 \%$ & $0.14 \%$ & $-8.30 \%$ \\
\hline
\end{tabular}


Table 2.The supply and demand balance analysis of water resources in urban area Unit: $10^{4} \mathrm{~m}^{3}$ (Basic planning year 2020)

\begin{tabular}{llll}
\hline Scheme & $\mathrm{P}=50 \%$ & $\mathrm{P}=75 \%$ & $\mathrm{P}=95 \%$ \\
\hline $\begin{array}{l}\text { Water } \\
\text { Supply }\end{array}$ & 15856.92 & 14359.795 & 11797.823 \\
Water & 14350.50 & 14350.50 & 14350.50 \\
$\begin{array}{l}\text { Demand } \\
\text { Water }\end{array}$ & 1506.43 & 9.30 & -2552.67 \\
$\begin{array}{l}\text { Shortage } \\
\begin{array}{l}\text { Water Short- } \\
\text { ageRate }\end{array}\end{array}$ & $10.50 \%$ & $0.00 \%$ & $-17.79 \%$ \\
\hline
\end{tabular}

Table 3.The supply and demand balance analysis of water resources in urban areaUnit: $10^{4} \mathrm{~m}^{3}$ (Recommended planning year 2012 )

\begin{tabular}{llll}
\hline Scheme & $\mathrm{P}=50 \%$ & $\mathrm{P}=75 \%$ & $\mathrm{P}=95 \%$ \\
\hline $\begin{array}{l}\text { Water } \\
\text { Supply }\end{array}$ & 12035.14 & 10378.515 & 8334.543 \\
Water & 8484.51 & 8484.51 & 8484.51 \\
$\begin{array}{l}\text { Demand } \\
\text { Water }\end{array}$ & 3550.63 & 1894.00 & -149.97 \\
$\begin{array}{l}\text { Shortage } \\
\begin{array}{l}\text { Water Short- } \\
\text { ageRate }\end{array}\end{array}$ & $41.85 \%$ & $0.22 \%$ & $-1.77 \%$ \\
\hline
\end{tabular}

Table 4.The supply and demand balance analysis of water resources in urban areaUnit: $10^{4} \mathrm{~m}^{3}$ (Recommended planning year 2020)

\begin{tabular}{llll}
\hline Scheme & $\mathrm{P}=50 \%$ & $\mathrm{P}=75 \%$ & $\mathrm{P}=95 \%$ \\
\hline $\begin{array}{l}\text { Water } \\
\begin{array}{l}\text { Supply } \\
\text { Water De- }\end{array}\end{array}$ & 15856.92 & 14359.795 & 11797.823 \\
mand & & & \\
$\begin{array}{l}\text { Water Short- } \\
\text { age }\end{array}$ & 2801.31 & 1304.19 & -1257.79 \\
$\begin{array}{l}\text { Water Short- } \\
\text { ageRate }\end{array}$ & $21.46 \%$ & $0.10 \%$ & $-9.63 \%$ \\
\hline
\end{tabular}


Seen from the table1to table 4, the basic and recommended schemes are water shortage in especially dry years $(\mathrm{P}=95 \%)$. In the basic scheme, the water shortage rate is $8.3 \%$ in $2012,17.79 \%$ in 2020. In the recommended scheme, the water shortage rate is $1.77 \%$ in $2012,9.63 \%$ in 2020 . In other years, the water supply meets the demand.

\section{Results analysis of water resources allocation scheme}

In this research, the optimization models are used for optimal calculation of different supply and demand scheme in the planning year (in 2020). The distribution relationship between various water sources is determined in urban areas. By summary, we can obtain total water shortage amount, water consumption structure of users, guaranteed rate of water supply and other indicators in different levels years. Finally, the optimal allocation of water resources is given under supply and demand scheme in different levels years.

In the supply and demand scheme in 2020, in addition to consideration of population, GDP's growth, according to the results of integrated water resources plan, the development of water-saving technology is also taken into account. The water consumption quota of different industries is cut, in order to achieve efficient use of water resources. With respect to the current year, wastewater reuse rate of urban area further improve. It is subject to the national and provincial water resources management concept based on the restriction on total water consumption, to develop the use of nonconventional water resources, shown Table 5 to Table 7.

\section{Listing and numbering}

Table5 .Different Water Resources Allocation Plan (in 2020, $\mathrm{P}=50 \%$ ) Unit: $10^{4} \mathrm{~m}^{3}$

\begin{tabular}{llcrrl}
\hline Scheme & Water & L & P & E & A \\
\hline Local & SW & 0 & 5877.81 & 29.12 & 5906.93 \\
water & GW & 0 & 1434.28 & 0 & 1434.28 \\
& NCW & 0 & 0 & 804.28 & 804.28 \\
\hline Guest & HQ & 2617.14 & 1032.86 & 0 & 3650.00 \\
water & DW & 327.14 & 302.91 & 0 & 630.06 \\
& JX & 327.14 & 302.91 & 0 & 630.06 \\
& QY & 0 & 0 & 0 & 0 \\
& CS & 0 & 0 & 0 & 0 \\
\hline
\end{tabular}

Notes: 1 .In the first row, $\mathrm{L}$ for life, $\mathrm{P}$ for production, $\mathrm{E}$ for ecology, A for amount.

2. In local water column, SW for surface water, GW for groundwater, NCW for nonconventional water, WSA for water supply amount.

3. In guest water, HQ is for Huangqian reservoir, DW for Dongwu village, JX for Jiuxian village, QY for Queyu reservoir, CS for Caishan reservoir.

Table 6 . Different Water Resources Allocation Plan (in 2020, P = 75\%) Unit: $10^{4} \mathrm{~m}^{3}$

\begin{tabular}{|c|c|c|c|c|c|}
\hline Scheme & Water & $\mathrm{L}$ & $\mathrm{P}$ & E & A \\
\hline Local & SW & 0 & 4679.9 & 29.12 & 4709.1 \\
\hline \multirow[t]{2}{*}{ water } & GW & 0 & 1337.27 & 0 & 1337.3 \\
\hline & NCW & 0 & 0 & 804.28 & 804.28 \\
\hline \multirow[t]{6}{*}{$\begin{array}{l}\text { Guest } \\
\text { water }\end{array}$} & \multicolumn{5}{|c|}{6} \\
\hline & DW & 327.14 & 767.86 & 0 & 1095.0 \\
\hline & JX & 327.14 & 1132.8 & 0 & 1460.0 \\
\hline & \multicolumn{5}{|c|}{6} \\
\hline & QY & 0 & 0 & 0 & 0 \\
\hline & $\mathrm{CS}$ & 0 & 0 & 0 & 0 \\
\hline
\end{tabular}


Table 7. Different Water Resources Allocation Plan (in 2020, $\mathrm{P}=95 \%$ ) Unit: $10^{4} \mathrm{~m}^{3}$

\begin{tabular}{cccccc}
\hline $\begin{array}{c}\text { Schem } \\
\text { e }\end{array}$ & $\begin{array}{c}\text { Wa- } \\
\text { ter }\end{array}$ & L & P & E & A \\
\hline Local & SW & 0 & 2398. & 29. & 2427. \\
water & & & 6 & 1 & 7 \\
& GW & 0 & 17929 & 0 & 1792. \\
& & & & & 9 \\
& NC & 0 & 0 & 80 & 804.2 \\
& W & & & 4 & 8 \\
\hline Guest & HQ & 2617 & 1032. & 0 & 3650. \\
water & & .1 & 9 & & 0 \\
& DW & 327. & 767.8 & 0 & 1095. \\
& & 1 & 6 & & 0 \\
& JX & 327. & 1132. & 0 & 1460. \\
& & 1 & 9 & & 0 \\
& QY & 0 & 254.7 & 0 & 254.7 \\
& & & 0 & & \\
& CS & 0 & 313.3 & 0 & 313.3 \\
& & & 0 & &
\end{tabular}

Note: 1 . The water shortage is $25,526,700 \mathrm{~m}^{3}$ in the basic scheme, so the water of Dongping Lake is transferred.

2. The water shortage is $12,577,800 \mathrm{~m}^{3}$ in the recommended scheme, so the water of Dongping Lake is transferred.

Seen from Table 2to Table4, we can see two allocation schemes of water sources. When $\mathrm{P}$ is $50 \%$, the current supply pattern can meet water demand. When $\mathrm{P}$ is $75 \%$, in addition the current supply pattern, there are reserve water sources, such as Que Yu and Cai Shan reservoir, so the water still can meets water demand of urban area. When $\mathrm{P}$ is $95 \%$, the current supply pattern can't meet water demand. The water shortage is $25,526,700 \mathrm{~m}^{3}$ in the basic scheme, $12,577,800 \mathrm{~m}^{3}$ in the recommended scheme. So in especially dry years, the water of Dongping Lake is transferred to solve water shortage problems.

\section{CONCLUSIONS}

(1) With the completion of the storage project of Dawenheand the strengthening of Shengli Reservoir, urban Tai' an is facing a new water supply configuration. Accordingly, this paper establishes the water resource optimization allocation model. The objective function considers the maximal social benefit under the condition of water shortage. Constraint conditions include water supply volume, water delivery capacity, domestic water need as well as user priority and water supply priority.

(2) Based on different water sources in the planning year, it provides two water allocation plans based on domestic, production and ecological water use as well as technical support for water administration in an effort to adjust water consumption policy

\section{REFERENCES}

[1]Wang Weirong, Lingling Zhang. Water resources allocation analysis under background of the most strict water resources management system[J].Water Resources and Power, 2014, 32(2):3841.(in Chinese)

[2]Shouping Zhang, Chuanjiang Wei, Hao Wang, et al. Basin/region water quality and quantity allocation I. Theory and method[J].Journal of Hydraulic Engineering, 2014, 45(7):757-766.(in Chinese) 
[3]Furong Du, Changsheng Du. Research on water demand forecasting and optimized allocationabout water resources in Jiaozuo City[J].Water Resources and Power, 2009, 27(4):25-28.(in Chinese)

[4]QitingZuo, Runfang Jin, Junxia Ma et al. China pursues a strict waterresources management system[J].Environmental Earth Sciences, 2014, 72(6):2219-2222.

[5] Shunjiu Wang, Xinli Zhang, Changjian Ni etc. Water Resource Optimization Principle and Method [M]. Beijing: China Water Conservancy and Hydropower Publishing House, 2007.

[6] Zening Wu, LishengSuo. Study on Water Resource Optimization Advancement. [J]. Journalof Irrigation and Drainage, 2004, 23(2):1-5.

[7] Yunzheng Jiang, Hongli Zhao, ZhiguoGan, etc. Reasonable Water Resource Allocation Based on Vapor Volume Index. [J]. Journal of Hydraulic Engineering, 2008, 39(6): 720-725.

[8] Ronghua Liu, Jiahuawei, Zhixiang Chen, etc. The Optimal Model of Talimu River Water Management [J], South-to-North water Diversion Project and Water Conservancy Science and Technology, 2009, 7 (1): 26-30. 